Article

\title{
Geomorphic Evolution of the Lilas River Fan Delta (Central Evia Island, Greece)
}

\author{
Efthimios Karymbalis ${ }^{1, *(\mathbb{D})}$, Kanella Valkanou ${ }^{1}$, Ioannis Tsodoulos ${ }^{1,2}$, George Iliopoulos ${ }^{3}$, \\ Konstantinos Tsanakas ${ }^{1}$, Vasilis Batzakis ${ }^{1}$, Giorgos Tsironis ${ }^{1}$, Christina Gallousi ${ }^{1}$, \\ Konstantinos Stamoulis ${ }^{2}$ and Konstantinos Ioannides ${ }^{2}$ \\ 1 Department of Geography, Harokopio University, 70 El. Venizelou Str., GR-17671 Athens, Greece; \\ elnel@otenet.gr (K.V.); itsodoul@cc.uoi.gr (I.T.); ktsanakas@geol.uoa.gr (K.T.); mpatzakis@gmail.com (V.B.); \\ t.giorgos00@gmail.com (G.T.); xgallousi@gmail.com (C.G.) \\ 2 Department of Physics, University of Ioannina, GR-45110 Ioannina, Greece; kstamoul@cc.uoi.gr (K.S.); \\ kioannid@cc.uoi.gr (K.I.) \\ 3 Department of Geology, University of Patras, GR-26504 Rio Achaia, Greece; iliopoulosg@upatras.gr \\ * Correspondence: karymbalis@hua.gr; Tel.: +30-210-954-9159
}

Received: 26 August 2018; Accepted: 25 September 2018; Published: 26 September 2018

\begin{abstract}
This paper presents the results of geomorphological investigations carried out on the Lilas River fan delta in central Evia Isl., Greece. A geomorphological map has been prepared using Digital Elevation Model analysis, aerial photos and Google Earth image interpretation, a reliable map of 1846, and extensive fieldwork. The Holocene sequence stratigraphy of the fan delta has been studied based on profiles of seven deep cores drilled by the municipal authorities. Two additional shallow boreholes were drilled with a portable drilling set and collected samples were analyzed using micropaleontological and grain size analysis methods while four sediment samples were dated using optically stimulated luminescence (OSL) techniques. During the early Holocene, most of the fan delta plain was a shallow marine environment. Between $4530 \pm 220$ and $3600 \pm 240$ years BP the depositional environment at the area of Nea Lampsakos changed from shallow marine to a lower energy lagoonal one. The main distributary changed its course several times leading to the building and subsequent abandonment of five fan delta lobes, through which the fan delta advanced during the late Holocene. The eastern part of the Kampos abandoned lobe is retreating with a maximum mean rate of $-0.94 \mathrm{~m}$ /year for the period 1945-2009, whereas the presently active mouth of the river and its immediate surrounds are prograding with a mean rate of about $+3.2 \mathrm{~m} /$ year.
\end{abstract}

Keywords: geomorphology; fan delta; Lilas River; Evia Isl.; Greece

\section{Introduction}

Much of the sediment transferred from land to sea is carried by rivers and deposited at the shoreline in the form of deltas and fan deltas. Deltas and fan deltas are important geomorphic and sedimentary environments, acting as major sinks for fluvially derived sediments in the coastal zone, as important ecological systems, and as foci for urban and agricultural development $[1,2]$. About $25 \%$ of the world's population lives on deltaic coastlines and wetlands [3]. River deltas are relatively complex systems and subject to a range of fluvial, climatic, tectonic, and sea-level controls [4,5]. Therefore, investigations of deltaic systems are of great interest because these areas represent a crucial link for understanding the interaction between fluvio-deltaic and marine sedimentation processes. Furthermore, deltas are sensitive to human-driven changes [6,7]. In recent centuries, anthropogenic activities—such as channelization, channel deviation, and damming-have generated sediment supply issues, altered natural processes, and changed the morphology of deltaic 
environments. Numerous studies have focused on the influence of both natural and human-induced changes on the evolution of worldwide deltas, such as the Yangtze [8], Huanghe [9], Mekong [10], Niger [11], Volta [12], Nile [13,14], Rhône [15,16], Ebro [17,18], Po [19,20], Danube [21,22], Arno [23], or Adra [24]. These studies generally analyzed the dynamics of the subaerial part of the delta, including the coastline, as well as human interventions, such as water extraction for irrigation and dam building.

Recent evolution of modern deltas as well as prediction of their growth and decay is critical in mountainous countries like Greece since the lack of extended plains suitable for cultivation enhances the important role of the low-lying deltaic areas for the local economic development. A large part of the low lands of mainland Greece are composed of deltaic plains [1,25,26]. The evolution of larger deltaic and coastal depositional systems in Greece has been relatively extensively studied [27-34]. The beginning of the evolution of nearly all Greek deltas is the same: during the Last Glacial Maximum around 20,000 years ago, sea-level fell to its lowest point, $120 \mathrm{~m}$ below that of today [35]. From 14,000 BP onwards, sea-level rose at an average speed of $1.5 \mathrm{~cm} /$ year, presumably reaching its present position (or close to it) around 6000-5500 BP [36]. In the following 5500 or so years, the significant expansion of Greek deltas occurred since many of the former marine embayments silted up, mainly due to fluvial sedimentation $[1,37]$.

The present study is a preliminary approach aiming at a better understanding of the dominant processes which contributed to the evolution and recent geomorphic configuration of the Lilas River fan delta, located in central Evia Island, Greece, during the Holocene. For the purpose of this paper, a detailed geomorphological map of the fan delta has been prepared through digital elevation model (DEM) analysis, extensive fieldwork, and comparative examination of aerial photographs, Google Earth images and a reliable map of the 19th century. For the study of the Holocene sedimentary stratigraphy of the fan delta descriptions of sedimentary profiles of seven deep drill cores were considered. Two shallow boreholes were drilled with a portable drilling set and OSL ages were obtained for four samples collected from one of the drill cores.

\section{Study Area}

The fan delta of the Lilas River (Lelantine plain) is located in Evia Isl., east of the city of Chalkis. Itis an arcuate type fan delta of approximately $30 \mathrm{~km}^{2}$ with a mean gradient of $0.7 \%$ and a curved shoreline. It extends mainly towards the South Evoikos Gulf with a secondary extension towards the North Evoikos Gulf (Figure 1).

According to the delta classification schemes [5], it should be classified among those mainly dominated by fluvial sediment supply, wave action, and longshore drift. This is obvious from the relatively straight to gently curved shoreline and the presence of palaeo-lobes. The formation of the Lilas River fan delta is the result of the combination of suitable conditions for delta formation both within the river catchment and the receiving basin (South Evoikos Gulf) during the late Holocene.

\subsection{The Lilas River Drainage Basin}

The Lilas River trends to the northeast as far as the peaks of Dirfys Mt. Its drainage basin has an area of about $300 \mathrm{~km}^{2}$ flowing into the South Evoikos Gulf (Figure 1). The drainage basin-fan delta system can be divided morphologically into four sections: (1) the upper mountainous area at Dirfys Mt., which is the oldest of all (pre-Neogene in age); (2) the intermediate, intermontane section which consists of Pliocene lacustrine formations; (3) the downstream hilly area; and (4) the Holocene fan delta, known also as the Lelantine plain, which has developed at the mouth of the river. The catchment consists of $32.8 \%$ easily erodible lacustrine formations (mainly conglomerates, marls, sandstones, and clays of Pliocene age), 28.2\% calcareous sedimentary rocks (mainly Mesozoic limestone), 27.2\% metamorphic rocks (mainly schist), 6.0\% igneous rocks (ultrabasic rock masses, labelled as ophiolites in Figure 2), and 5.7\% of unconsolidated sediments (mainly alluvial deposits along the channels of the main streams) [38] (Figure 2). The general climatic conditions of the catchment 
are typical of the temperate Mediterranean. The mean annual precipitation ranges from $450 \mathrm{~mm}$ near the coastline to $550 \mathrm{~mm}$ in the north-northeasternmost highlands while the mean annual temperature fluctuates between $15^{\circ} \mathrm{C}$ and $16^{\circ} \mathrm{C}$ [39].

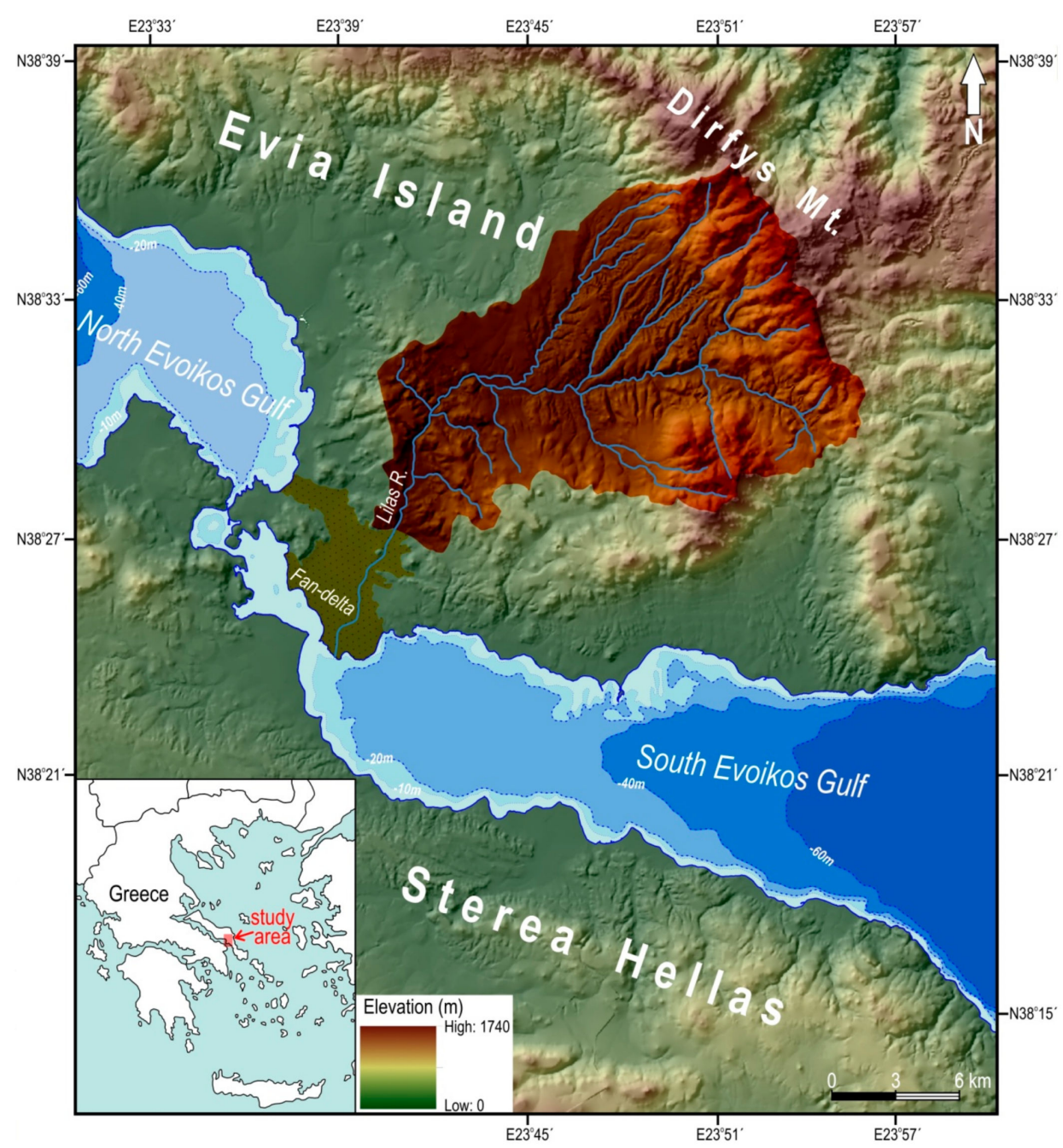

Figure 1. Digital elevation model (DEM) of the broader area of the Lilas River catchment and fan delta. The bathymetry of the northern part of the South Evoikos Gulf as well as the southern part of the North Evoikos Gulf are also depicted.

Climate conditions within the drainage basin along with its bedrock geology (extensive presence of highly erodible formations) and relief (relatively steep slopes in the upper reaches) are characteristics favorable for weathering and erosion in the area of the catchment. Hence large amounts of sediments supplied by erosion are transported down the valley of the river to the coast.

\subsection{South Evoikos Gulf: The Receiving Basin}

The South Evoikos Gulf is one of a series of Neogene basins that has subsided since the Miocene in central Greece [40]. According to several seismotectonic studies in the broader area of the Evoikos Gulf, its Northern part is characterized by very pronounced faulting tectonics, associated with powerful destructive earthquakes [41-43]. In contrast, the Gulf's central and southern parts, where the Lilas River fan delta is located, are considered areas of mild tectonic activity and moderate seismicity [44,45]. There are no large tectonic structures in the vicinity of the central Evoikos Gulf and earthquakes are usually of low magnitude. Although earthquakes recorded in 1853, 1894, 1914, and 1938 affected the city of Chalkis and its immediate surroundings, most of them had little wider impact [1,46,47]. 
The northern margin of the South Evoikos Gulf is defined by the W.NW-E.SE directed Lefkandi normal fault. The fault dips to the south, continues offshore for a total length of $25 \mathrm{~km}$, south of the modern towns of Eretria and Amarynthos [45,48] and affects the southeastern part of the Lilas River fan delta plain. The trace of the fault in the fan delta plain has been mapped in detail by Rondoyanni et al. [45] using geophysical techniques. An average fault slip rate of $1 \mathrm{~mm} /$ year for the last 150,000 years is estimated, which is significantly smaller than that of the faults delimiting the graben of the North Evoikos Gulf (3 mm/year) [49]. A smaller fault directed also W.NW-E.SE and dipping to the south outcrops near the village Vassiliko. It has a visible length of $5 \mathrm{~km}$, whereas tectonic striations on the fault surface indicate a recent fault reactivation [45].

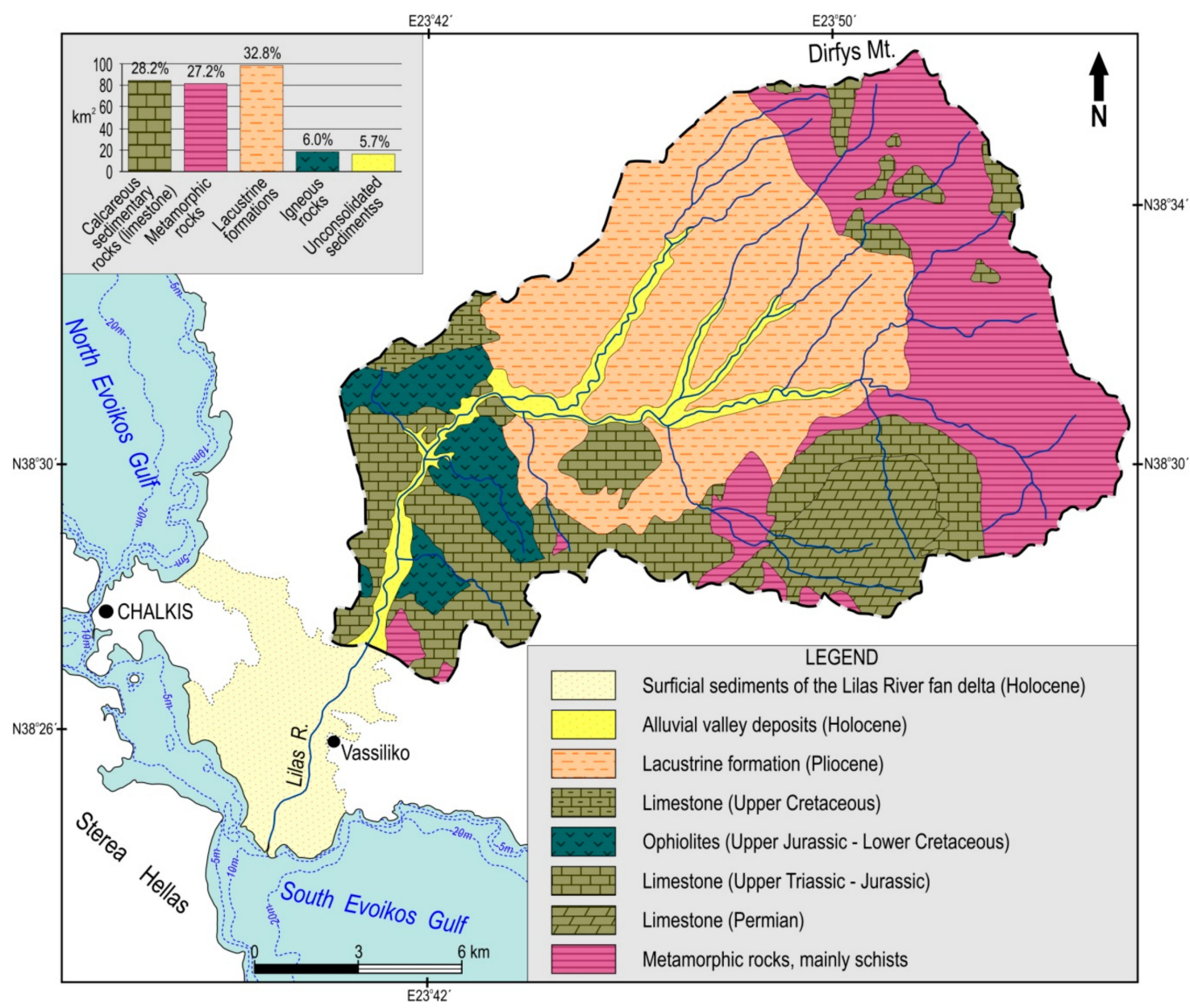

Figure 2. Simplified lithological map of the Lilas River drainage basin with a diagram showing the percentage area of each one of the lithological types in the catchment. It is based on the Greek Institute of Geology and Mineral Exploration (IGME) 1:200,000 scale geological map of Greece [38].

Water depths over the South Evoikos Gulf range from 20 to $68 \mathrm{~m}$ and the seafloor relief is characterized by low gradients (1:1000) [50]. According to the output of a wave model (POSEIDON reasearch program), which has been calibrated with the use of offshore field measurements, the wave climate of the fan delta coastline is dominated by offshore significant wave heights $\leq 0.1 \mathrm{~m}$ [51]. Tidal range at the Euripus, the narrowest point in the Evoikos Gulf, has been accurately measured for the last 50 years and shows its maximum amplitude $(0.56 \pm 0.05 \mathrm{~m})$ in north Chalkis [52]. Some authors consider it to be the largest tide recorded along the Greek Aegean coastline [52,53], though Tsimplis [54] records a distinction between north Chalkis, where the daily tide is around $0.5 \mathrm{~m}$, and south Chalkis where values are closer to $0.2 \mathrm{~m}$. 
It is therefore obvious that the characteristics of the receiving basin (relatively low tidal range, waves, and longshore currents not strong enough to remove all, or at least most, of the sediments deposited by the river and relatively gentle slope of the sea floor around the Lilas River mouth) have permitted long-term sediment accumulation and the advance of the fan delta.

\section{Data and Methods}

This work has combined geomorphological mapping with the study of the stratigraphy of late Pleistocene-Holocene deltaic sediments. A detailed geomorphic map has been produced showing both the deltaic plain and the coastal zone features using GIS techniques. A $5 \times 5$ cell size DEM, produced by detailed topographic sheets (at 1:5000 scale) with a good contour density (4 m contour interval, as well as $1 \mathrm{~m}$ in the relatively flat low-lying regions) obtained from the Hellenic Military Geographical Service, was utilized for the geomorphological mapping of the fan delta together with extensive fieldwork. In addition, a series of georeferenced aerial photos taken in 1945 and 2009 along with Google Earth images and a reliable map of the 19th century allowed us to identify the main landforms as well as the recent changes of the fan delta morphology.

Profiles of seven drill cores up to the depth of $70 \mathrm{~m}$, provided by the municipality authorities, were considered in order to describe the late Pleistocene-Holocene sedimentary stratigraphy of the broader fan delta plain. Additionally, two boreholes extending down to depths of $4.75 \mathrm{~m}$ (LIL1), and $3.78 \mathrm{~m}$ (LIL2), were collected from two of the former fan delta lobes (east and west of the presently active distributary channel), with a portable drilling set. The shallow cores were granulometrically and palaeontologically analyzed in order to draw conclusions about the depositional evolution and the late Holocene palaeoenvironmental history of the deltaic plain. Forty-one sediment samples were taken from selected layers at decimeter intervals. Wet sieving was performed on all sediment samples. Eight sieves were used, ranging in diameter from $4 \mathrm{~mm}$ for the coarser particles to $45 \mu \mathrm{m}$ for the finer ones and percentage distribution by weight of silt-clay $(<63 \mu \mathrm{m})$, sand $(63 \mu \mathrm{m}-2 \mathrm{~mm})$, and gravel (>2 mm) particles of the matrix material was estimated for each sample. Thirty-six samples were analyzed for palaeontological analyses aiming at the determination of the depositional environment. For that purpose, selected samples were studied from the collected cores to assess their environmental character and stratigraphic position. These samples were processed using traditional macro and micropalaeontological techniques for calcareous macro and microfossils (mollusks, foraminifera, and ostracods). The material $>125 \mu \mathrm{m}$ of the washed residue was semi-quantitatively picked for all biogenic components under a light microscope. Foraminifera, ostracodes, gastropods, and bivalves were identified to the species level where possible.

To establish a chronostratigraphy of the shallow drill core LIL1 apart from the micropalaeontological and grain size analyses, four samples were collected for optically stimulated luminescence (OSL) dating. Sub-sampling and sample preparation were carried out at the Physical Geography laboratory of the Harokopio University of Athens, under subdued red light conditions to avoid resetting the light-sensitive OSL signals, while the luminescence measurements took place at the Archaeometry Center of the University of Ioannina. The outer $\sim 1 \mathrm{~cm}$ from the face of the half core and the contact with the wall of the core was discarded. The samples were subjected to wet-sieving to obtain the 100-150 $\mu \mathrm{m}$ fractions, from which purified quartz grains were obtained by standard laboratory procedures (e.g., [55]). The purity of the extracted quartz grains was checked using the OSL-IR depletion ratio [56]. The chemically purified quartz grains were mounted on $10 \mathrm{~mm}$ diameter stainless steel discs by covering a part with 3-4 $\mathrm{mm}$ diameter at the center of the disc [57] using acetone suspension. Luminescence measurements were performed on a Risø TL/OSL-DA-20 reader (DTU Nutech, Roskilde, Denmark) equipped with blue $(470 \mathrm{~nm}$ ) LEDs and a $7 \mathrm{~mm}$ Hoya U-340 optical detection filter [58]. The single-aliquot regenerative-dose (SAR) protocol of Murray and Wintle [59] was used to determine all equivalent doses (De). All OSL measurements were made using stimulation with blue diodes at $125^{\circ} \mathrm{C}$ for $40 \mathrm{~s}$. The OSL signal was calculated using the initial $0.8 \mathrm{~s}$ minus a background from the mean of the last $8 \mathrm{~s}$ of the stimulation curve at $90 \%$ LED power. 
For all OSL measurements, a preheat temperature of $220^{\circ} \mathrm{C}(10 \mathrm{~s})$ and acute heat temperature of $160{ }^{\circ} \mathrm{C}(0 \mathrm{~s})$ were selected after performing a dose recovery-preheat plateau test on a representative sample using different preheat temperatures. Measurements were rejected if recycling ratios exceeded $10 \%$ from unity and recuperation exceeded $5 \%$ of the natural signal. The environmental dose rates were calculated from radionuclide concentrations, measured by high-resolution gamma spectrometry, using the conversion factors of Liritzis et al. [60]. The dose rates were calculated using the DRAC software (Dell, Round Rock, TX, USA) (v1.1; [61]).

\section{Results and Discussions}

\subsection{Geomorphology of the Fan Delta}

The geomorphological map shows that the dominant process for the recent development of the fan delta is fluvial sedimentation (Figure 3). The present-day active distributary channel flows in a N.NE-S.SW direction and maintains a braided pattern, which is indicative of the large sediment load of the river. Nearly $2 \mathrm{~km}$ upstream from the river mouth, at the location where the trace of Lefkandifault crosses the channel, the river changes its course from N.NE-S.SW to E.NE-W.SW for a short distance. Hence the distributary channel must have been affected by the W.NW-E.SE trending normal fault of Lefkandi the trace of which has been mapped in detail by Rondoyanni et al. [45] using geophysical techniques. It should be noted here that during the field work we did not identify any knick-point (vertical offset) but the analysis of the DEM shows that the channel upstream from this point has a slightly lower gradient compared with the slope of the channel downstream. This change of the course of the main channel is not visible on the Thomas Graves' map, which was published in 1848. Thus it can be attributed to the activation of the Lefkandi fault by the post 1848 earthquakes that affected the broader area. As mentioned above three earthquakes occurred in 1894, 1914, and 1938 respectively affecting the city of Chalkis and its immediate surroundings [1,46,47]. There are no indications that the smaller Vassiliko fault had any discernible impact on the evolution and morphology of the fan delta.

The dominant landforms of the fan delta plain are the numerous abandoned distributaries. Most of these palaeo-channels, which are clearly visible in the 1945 aerial photographs, are no longer identifiable in the fan delta landscape. Thus, aerial photographs of 1945 have been particularly useful for recognizing and mapping these landforms. The survey of the 1848 historical map of the fan delta and aerial photos allowed the identification of five groups of palaeo-distributaries and associated abandoned river mouths which outline changes in the river course and migration of the active mouth of the river. One major former river mouth, associated with channel avulsion, has been identified east of the present active mouth, whereas there are four more west of it. The most recently abandoned river course is a channel west of the present active one. This channel, which is depicted in a bathymetric chart of the western part of the Evripos channel surveyed in 1846-1847 by Thomas Graves (published in 1848) [62], leads to Bourtzi, about $1 \mathrm{~km}$ northwest of the present active mouth of the river (Figure 3).

Further to the west, two major former river mouths (at Agios Nikolaos and NeaLampsakos) associated with channel avulsion, have been identified $1.6 \mathrm{~km}$ and $3 \mathrm{~km}$ northwest of Bourtzi, respectively (Figure 3). The avulsion points are located 4.5 and $5.8 \mathrm{~km}$ upstream from the active river mouth. Hence, a change from active channel deposition in the western delta to active deposition in the central delta occurred. The westernmost palaeo-channels system begins from the apex of the fan delta, passes through the northwestern secondary extension of the fan delta plain and ends at Liani Ammos of the North Evoikos Gulf. The northwesternmost channel of this group has a meandering pattern and is clearly visible in Google Earth images and thus must be relatively recent. The fan delta lobe of Kampos, east of the active river mouth, advanced by the sediment supply through a group of now abandoned channels (both straight and meandering) which begin $2.5 \mathrm{~km}$ upstream from the active river mouth. The abandoned distributaries of Bourtzi and Agios Nikolaos have been recently activated during a severe rainfall event which happened on 11-12 September 2009. Approximately $350 \mathrm{~mm}$ of rainfall in $28 \mathrm{~h}$ was recorded at the meteorological station closest to the study area when average 
rainfall for September is about $10 \mathrm{~mm}$. The extreme discharge caused levee failures and resulted in flooding of the low-lying part of the fan delta plain.

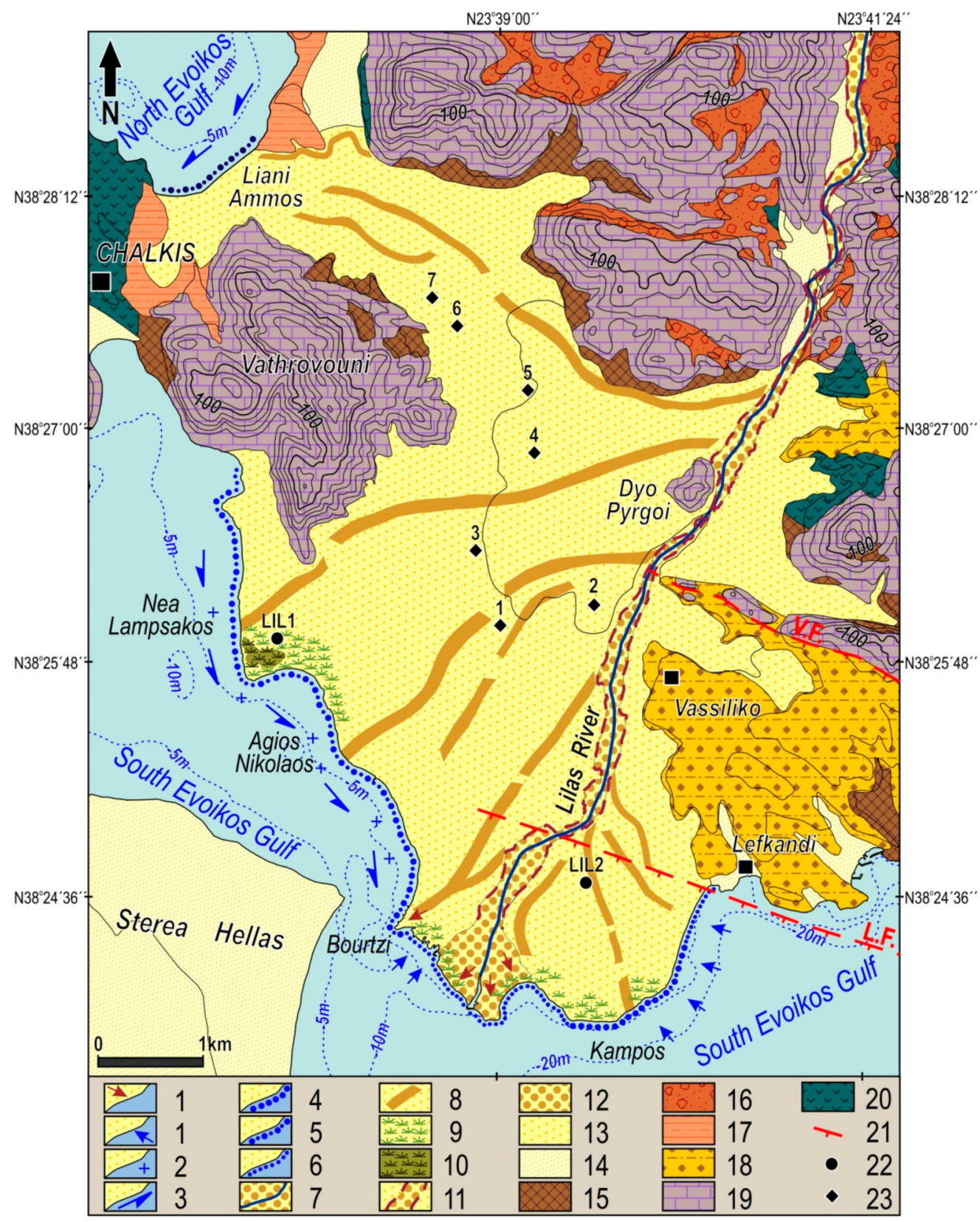

Figure 3. Geomorphological map of the Lilas River fan delta. Legend: 1: prograding/retreating coastline, 2: stable coastline, 3: prevailing longshore drift, 4: gravelly beach, 5: beach with mixed material, 6: sandy beach, 7: presently active channel, 8: abandoned channel, 9: ephemeral coastal marsh, 10: perennial coastal marsh, 11: natural levees, 12: channel deposits, 13: fan delta surficial sediments, 14: alluvial deposits, 15: scree and talus cones, 16: terrestrial formations (red fine grained materials with dispersed cobbles and rubbles) of Pleistocene age, 17: brackish deposits (conglomerates-sandstones-marls) of Upper Pliocene-Lower Pleistocene age, 18: lacustrine and fluvial deposits (conglomerates-sandstones-marls) of Upper Miocene age, 19: limestone (Middle Triassic-Middle Jurassic), 20: ultrabasic rocks, 21: fault, 22: location of shallow drill cores conducted for this study, 23: location of the deep drill cores provided by the municipal authorities. L.F.: Lefkandi Fault, VF: Vassiliko Fault. 
This severe flash flood event was accompanied by a storm surge which caused extensive damage at the settlements of Bourtzi and Agios Nikolaos as well as the retreat of the marshy area northwest of the active mouth of the river.

The comparable analysis of the digitized fan delta shorelines of 1945 and 2009 shows that most of the coastline (particularly along the North Evoikos Gulf as well as part of the coastline northwest of the present active mouth of the river) is generally stable due to relatively long-term quiet marine conditions. The section of the fan delta coastline from Bourtzi to Nea Lampsakos is sheltered from big waves since the fetch is short and the waters are shallow (the maximum depth is $12 \mathrm{~m}$ ). On the other hand, the section of the coastline extending from the mouth of the river to the eastern edge of the delta is more exposed to wave activity (particularly to E and SE wave approach directions). Approximately $2.1 \mathrm{~km}$ of the eastern fan delta coastline, is currently undergoing erosion. This change in coastline position is the result of redistribution of sediment from the abandoned lobe of Kampos (Figure 3). It is estimated that the maximum shoreline retreat at this part of the fan delta was about $60 \mathrm{~m}$ over the 64-year period between 1945 and 2009 (corresponding to a maximum mean erosion rate of $-0.94 \mathrm{~m} /$ year). In contrast, the area around the presently active mouth of the river has prograded for about $500 \mathrm{~m}$ from 1846 to 2009 (mean aggradation rate: $+3.1 \mathrm{~m} /$ year). It should be noted that after 1846, the river shifted to its present position. For the period between 1945 and 2009, the presently active mouth of the river and its immediate surrounds advanced with a mean long-term progradation rate of about $+3.2 \mathrm{~m} /$ year. It is worth mentioning that nearly $0.7 \mathrm{~km}$ of the coastline along the Bourtzi marshy wetland, northwest of the river mouth, has suffered severe erosion, probably associated with the aforementioned 2009 extreme weather event. The wetland lost about $0.2 \mathrm{~km}^{2}$ while the shape of the coastline changed significantly from straight to jagged and part of the coastal road was destroyed.

\subsection{Stratigraphy of the Fan Delta}

According to the deep drill core logs, the limestone basement is found at Skourbi and DyoDendra at the depths of $71 \mathrm{~m}$ ( $50 \mathrm{~m}$ below present sea-level) and $50 \mathrm{~m}$ ( $40 \mathrm{~m}$ below present sea-level) respectively. In the broader area of Vassiliko-Mytikas-Skourbi-Govios and DyoDendra (Figure 4), there exists a sand layer with marine shells at depths of 10 to $20 \mathrm{~m}$ depending on the elevation of the fan delta surface [63]. The profiles of the drill cores show the horizon of the marine deposits which, depending on their location, range in depth from 7 to $25 \mathrm{~m}$ and corresponds very well to the present sea-level (Figure 4). This marine layer indicates that the sea reached the area of the present apex of the fan delta probably after the quick rise of the sea-level that followed the end of the last glacial period. This inundation possibly took place around 5000-5500 years BP when the rate of sea-level rise slowed down, as it can be assumed by the sea-level change curve proposed for the area of Eretria, which lies $12.5 \mathrm{~km}$ east of the Lilas fan delta $[64,65]$. The marine layer is overlaid by fluvio-torrential deposit which constitutes the recent Holocene sediments of the Lilas River. The thickness of this uppermost fluvio-torrential deposit ranges from $20.5 \mathrm{~m}$ to $7 \mathrm{~m}$ depending on the location of the core. At the secondary extension of the fan delta towards the North Evoikos Gulf (cores 6 and 7), the thickness is less than the other parts of the main fan delta plain. At Kinios (borehole 1), in this upper unit, an archaeological stratum is reported at a depth of 8-10 m (5-7 m above present sea-level) (Figure 4). In all the drill cores, there are silty clay sediments underlying the coastal marine deposits layer indicating a shallow coastal depositional environment of low energy [63]. At Skourbi and Govios, below the mud layer, there are well-cemented fluvio-torrential deposits indicating that the Holocene sea transgression drowned the fluvio-torrential deposits of the palaeo-valley system of the South Evoikos Gulf.

The shallow core LIL1 was drilled at the marshy area located at the Nea Lampsakos fan delta lobe, about $375 \mathrm{~m}$ from the present day shoreline at an absolute elevation of $0.3 \mathrm{~m}$ and reached a depth of $4.75 \mathrm{~m}$ (Figures 3 and 5). From the bottom of the core up to $2 \mathrm{~m}$ the stratigraphy consists mainly of silty sand with some layers rich in clasts, while from $2 \mathrm{~m}$ up to the top of the core the stratigraphy is dominated by sandy silt and clay (Figure 5). 


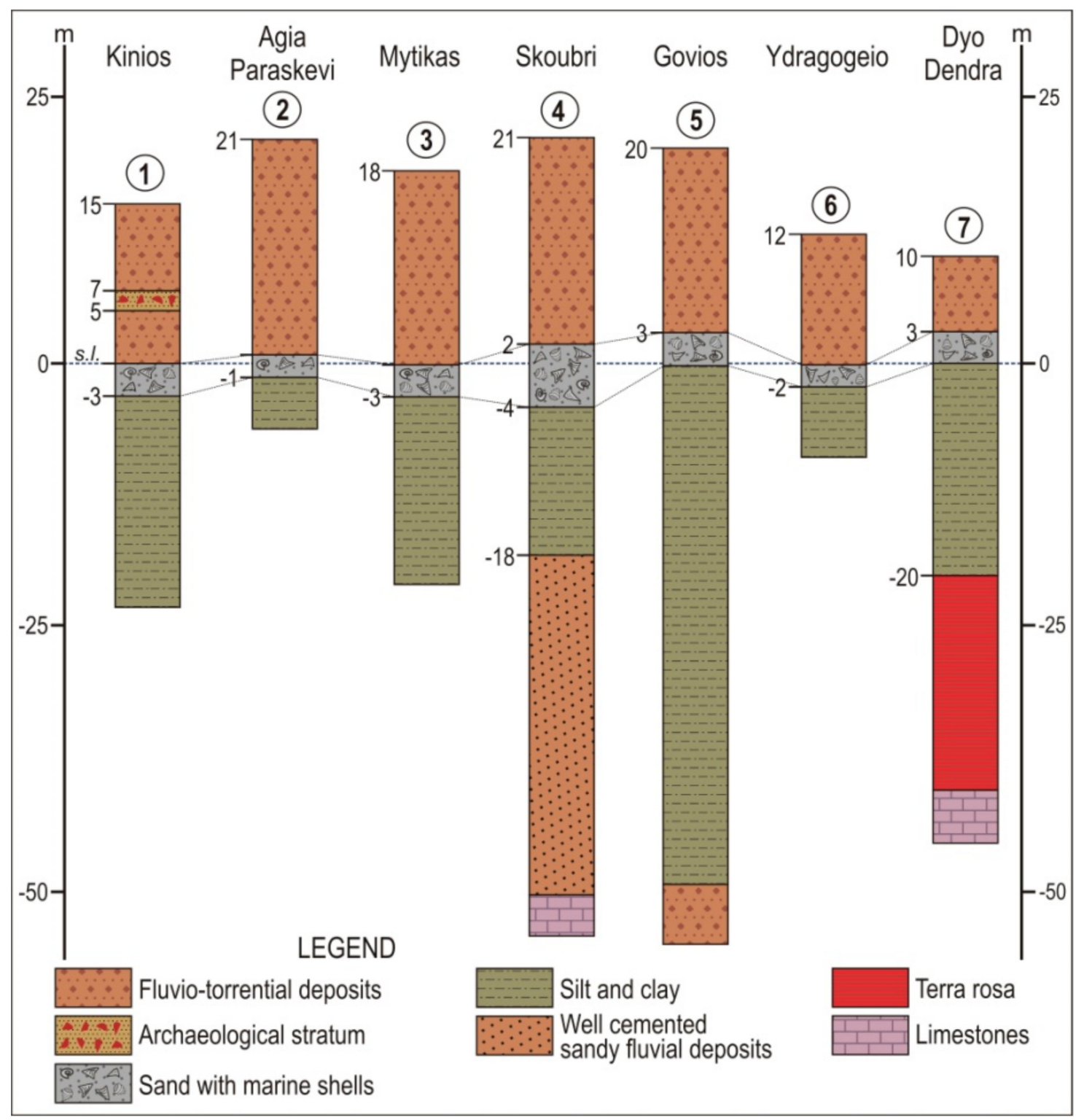

Figure 4. Profiles of seven deep drill cores from the Lilas River fan delta plain. The locations of the drill cores are shown on the map of Figure 3 (modified from Maroukian and Gaki-Papanastassiou [63]).

The results of the palaeontological analysis were relatively poor (Figure 5). Three samples (Samples 2, 11 and 32 collected from the depths of 0.35, 1.75 and 4.40 respectively) gave statistically valid results. Sample 2 can be characterized as lagoonal with limited marine influence since brackish species are found together with some marine/brackish and truly marine species. Sample 32 contains a higher percentage of marine/brackish and fully marine species. Sample 11 is characterized as lagoonal with riverine influence. In this sample, only brackish and low salinity ostracode species (mainly Cypridopsisvidua and Ilyocyprisbradyi) were found. Additionally, shell fragments were also present in many samples, especially below the depth of $2 \mathrm{~m}$ under the surface. However, their identification was not possible as less than $50 \%$ of the shell was maintained. From 0.08 to $2 \mathrm{~m}$ depth shell fragments were not found. In contrast, many shell fragments were found from 2 to $4.75 \mathrm{~m}$ implying a depositional environment of higher energy. In this unit, plant remains were also found in some samples (e.g., samples 18, 19, 20, and 21-depth 2-2.63 m-and samples 29, 30, and 31-depth $3.7-4.2 \mathrm{~m}$ ). In these intervals a terrestrial influence is possible. 


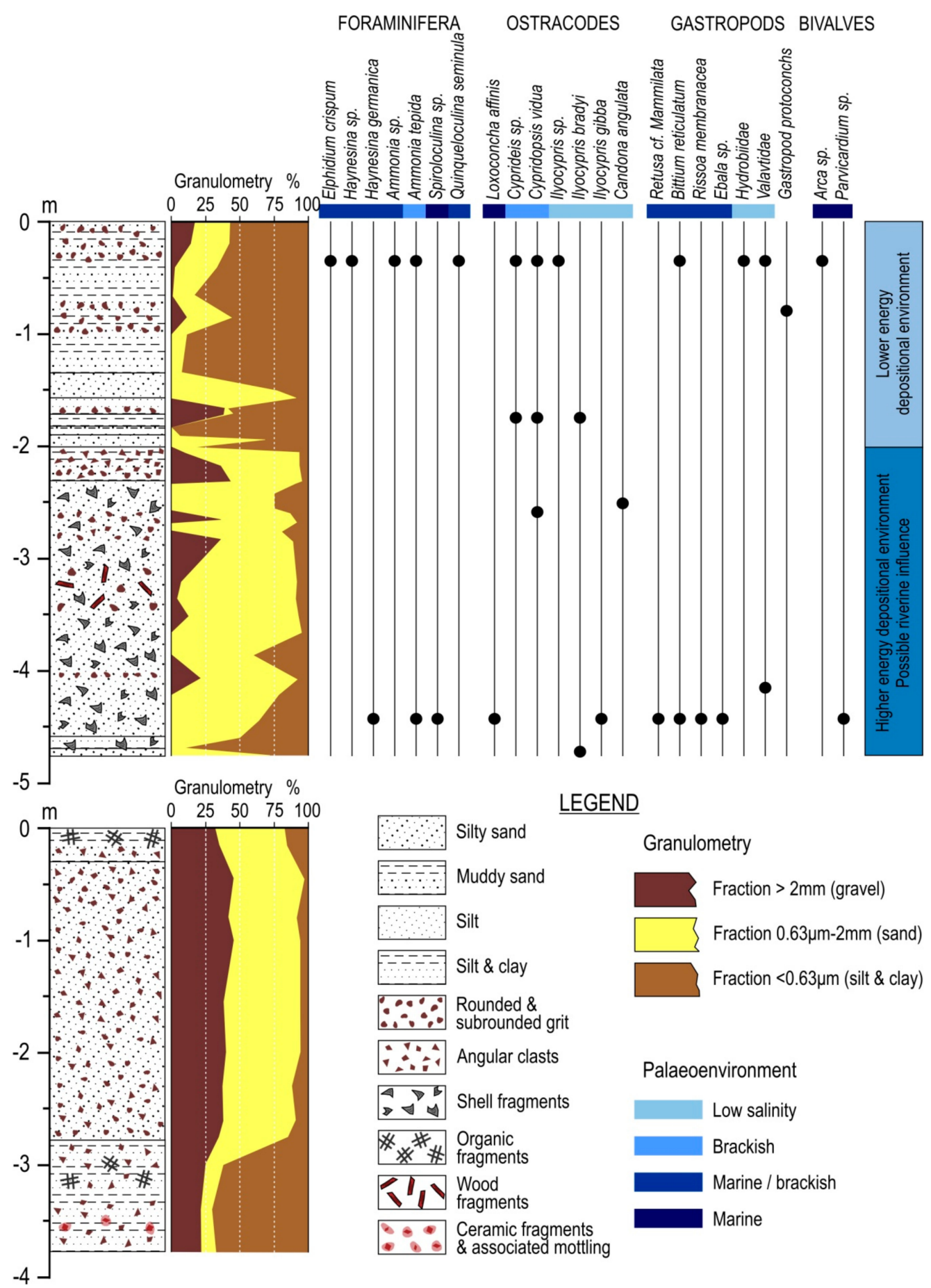

Figure 5. Core profiles of LIL1 and LIL2. The results of the grain size analyses along with the results of the paleontological analyses are also presented. The locations of the drilled cores are shown on the map of Figure 3.

The OSL dating results of the collected samples provide valuable information about the chronostratigraphy of the late Holocene sedimentary sequence of the Nea Lampsakos fan delta lobe. OSL ages for the samples from core LIL1 are presented in Table 1. Sample LILOSL04 was collected from the base of the borehole (at the depth of $4.7 \mathrm{~m}$ ) and yielded an age of $7090 \pm 270$ years BP. Two samples (LIL1OSL03 and LIL1OSL02) were collected from the depths of 2.4 and $2.3 \mathrm{~m}$ (ages $6580 \pm 310$ and $4530 \pm 220$ years BP, respectively) since a change in the depositional environment has been identified 
by the grain size analysis and the paleontological study of the sediments at the depth of $2 \mathrm{~m}$. Finally, a fourth sample (LIL1OSL01) from the depth of $1.5 \mathrm{~m}$ yielded an age of $3600 \pm 240$ years BP.

Table 1. Radionuclide concentrations, dose rates, equivalent doses, and OSL ages for samples collected from core LIL1.

\begin{tabular}{|c|c|c|c|c|c|c|c|c|c|c|}
\hline No & $\begin{array}{c}\text { Sample } \\
\text { ID }\end{array}$ & $\begin{array}{c}\text { Depth } \\
\text { Below } \\
\text { Surface }(\mathrm{m})\end{array}$ & $\begin{array}{l}\text { Water } \\
\text { Content } \\
\text { (\%) (a) }\end{array}$ & $\begin{array}{c}{ }^{238} \mathrm{U} \\
(\mathrm{Bq} / \mathrm{kg})^{(b)}\end{array}$ & $\begin{array}{c}{ }^{232} \mathrm{Th} \\
(\mathrm{Bq} / \mathrm{kg})^{(\mathrm{b})}\end{array}$ & $\begin{array}{c}{ }^{40} \mathrm{~K} \\
(\mathrm{~Bq} / \mathrm{kg})^{(\mathrm{b})}\end{array}$ & $\begin{array}{c}\text { Total } \\
\text { Dose Rate } \\
\text { (Gy/ka) }^{\odot}\end{array}$ & $\mathbf{N}^{(\mathrm{d})}$ & $\begin{array}{c}\text { Equivalent } \\
\text { Dose } D e \\
\text { (Gy) } \boldsymbol{\epsilon}^{\epsilon}\end{array}$ & $\underset{(f)}{\operatorname{Age}(k a)}$ \\
\hline 1 & & 1.5 & $16 \pm 10$ & $191+04$ & $337+05$ & $489.8 \pm 3.9$ & $2.25 \pm 0.04$ & $23(24)$ & $8.08 \pm 0.52$ & $3.60 \pm 0.24$ \\
\hline 2 & LIL1OSL02 & 2.3 & $9 \pm 10$ & $20.3 \pm 0.4$ & $32.8 \pm 0.5$ & $412.5 \pm 3.4$ & $2.18 \pm 0.03$ & $26(36)$ & $9.88 \pm 0.46$ & $4.53 \pm 0.22$ \\
\hline 3 & LIL1OSL03 & 2.4 & $17 \pm 10$ & $23.4 \pm 0.4$ & $34.5 \pm 0.5$ & $461.1 \pm 3.6$ & $2.21 \pm 0.04$ & $23(24)$ & $14.58 \pm 0.63$ & $6.58 \pm 0.31$ \\
\hline 4 & LIL1OSL04 & 4.7 & $39 \pm 10$ & $26.4 \pm 0.4$ & $36.1 \pm 0.5$ & $509.6 \pm 4.0$ & $1.97 \pm 0.05$ & $21(24)$ & $13.95 \pm 0.39$ & $7.09 \pm 0.27$ \\
\hline
\end{tabular}

(a) Water content expressed as percentage of the mass of dry sediment, calculated using field values.

(b) Concentrations of ${ }^{238} \mathrm{U},{ }^{232} \mathrm{Th}$, and ${ }^{40} \mathrm{~K}$ were determined from laboratory measurements using high-resolution

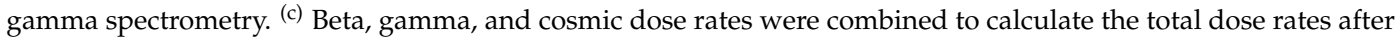
Aitken [66]. Betta and gamma dose rates were calculated using the conversion factors of Liritzis et al. [60]. Beta dose rates have been corrected for the effect of the water content, grain size and chemical etching. Gamma dose rates have been corrected for the effect of the water content. Cosmic dose rates were calculated according to Prescott and Hutton [67]. (d) The number of aliquots accepted/measured. (e) Equivalent dose values were determined using the central age model (CAM) of Galbraith et al. [68]. ${ }^{(f)}$ Ages before 2017 AD.

Based on the foraminifera, ostracodes and mollusk identification, as well as the sedimentological results, the lower unit is indicative of a shallow marine to slightly brackish environment of higher energy compared with the depositional conditions of the upper unit which was a lower energy brackish lagoonal environment. According to the OSL dating result, the lower unit can be dated from at least $7090 \pm 270$ years BP to sometime between $4530 \pm 220$ and $3600 \pm 240$ years BP (determined at 2.3 and $1.5 \mathrm{~m}$, respectively) where a change of the depositional environment occurred to a more sheltered lagoonal one. The results obtained from OSL dating suggest a high mean sediment accumulation rate of approximately $4.5 \mathrm{~mm}$ /year for the time period between $7090 \pm 270$ years BP and $6580 \pm 310$ years $\mathrm{BP}$, which is significantly higher than the mean sediment deposition rate $(0.2 \mathrm{~mm} /$ year $)$ estimated for the following 500 years (time period between $6580 \pm 310$ and $4530 \pm 220$ years BP). The 2050 year time lag (6580 $\pm 310-4530 \pm 220$ years) and the sudden facies change between 2.3 and $2.4 \mathrm{~m}$ may not correspond to a period of decreased sedimentation rate but it may indicate a rapid truncation event. Sediment accumulation increases for the next 930 years at a rate of $0.86 \mathrm{~mm} /$ year with the establishment of a very low-energy lagoonal environment sometime between $4530 \pm 220$ and $3600 \pm 240$ years BP due to the stabilization of sea-level. During the last $3600 \pm 240$ years lagoonal sediments deposit at a mean rate of $0.42 \mathrm{~mm} /$ year.

Borehole LIL2, located at the Kampos fan delta lobe, about $1.3 \mathrm{~km}$ from the present day shoreline at an absolute elevation of $6.5 \mathrm{~m}$, was drilled down to a depth of $3.8 \mathrm{~m}$ (Figures 3 and 5). The core consists exclusively of fluvio-terrestrial and overbank sediments (mainly silty sand with clasts) since the paleontological analysis of the collected samples showed no macro- or micro-fossils (Figure 5). From the bottom of the core up to the depth of $3.3 \mathrm{~m}$ (3.2 $\mathrm{m}$ a.s.1.) a $0.5 \mathrm{~m}$ thick sandy layer with clasts and ceramic fragments was observed. This layer possibly corresponds to the rich in ceramic fragments archaeological stratum found at the deep drill core 1 (at Kinios) 5-7 m a.s.l. (Figure 4).

\subsection{Palaeogeographic Evolution of the Fan Delta}

During the late Pleistocene, sea-level was much lower than its present position [35,36] and Lilas River was a tributary of a much larger drainage pattern which was active during the last glacial period up until early Holocene. The main channel of this palaeo-drainage network had an almost NW-SE direction flowing along the western part of the present South Evoikos Gulf, which was a valley during the early Holocene. This is evident both from the morphology of the South Evoikos Gulf (Figure 1) and from the results of the seismic stratigraphic investigation of the Gulf $[48,49]$. At the end of the last glacial period and the beginning of the quick rise of sea-level the valley system of the South Evoikos Gulf was drowned and the area of the present day Lilas River fan delta was under the sea. At about 
5000 years ago, the part of the fan delta plain between Dyo Pyrgoi and Liani Ammos was a shallow marine environment. This is proved by the evident presence of a relatively thin sandy layer with marine shells at depths of 10 to $20 \mathrm{~m}$ at the profiles of the seven deep drill cores from the upper fan delta plain (Figure 4). Hence for a short period of time, the mouth of the Lilas River was further upstream while North and South Evoikos Gulfs were joined and the broader area of the modern city of Chalkis and Vathrovouni hill was an island.

Like several deltas, the Lilas River fan delta started its development as bay-head delta in embayments and rias. After the slowdown of the sea-level rise 5000-5500 years BP [65] the fan delta advanced through distributaries which delivered sediment to the coast. The main distributary channel changed its course frequently leading to the building of at least five fan delta lobes (at today's Liani Ammos, Nea Lampsakos, Agios Nikolaos, Bourtzi, and Kambos), through which the fan delta has advanced. It should be noted here that avulsion and evolution of new distributary channels was a process driven by climate/fluvial factors. Distributary migration is a relatively frequent natural phenomenon in deltas dominated by fluvial sediment supply because hydraulic gradients decrease as rivers and distributaries extend their courses. Another reason for avulsion and evolution of a new distributary was the breach of the natural levees due to high river water levels during extreme rainfall events.

Particularly for the Nea Lampsakos palaeo-lobe the sedimentological and micropalaeontological analyses, along with the OSL dating results showed that from at least $7090 \pm 270$ years $\mathrm{BP}$ to $6580 \pm 310$ year BP, this part of the fan delta plain had a shallow marine to slightly brackish environment of higher energy with a mean sediment accumulation rate of $4.5 \mathrm{~mm} /$ year. Sometime between $4530 \pm 220$ and $3600 \pm 240$ years BP, a change of the environment occurred to a more sheltered lagoonal one with a significant lowering of the mean deposition rate (approximately $0.5 \mathrm{~mm} /$ year).

\section{Conclusions}

The formation of the Lilas River fan delta is the result of the combination of suitable conditions for delta formation during the late Holocene. Climate conditions within the drainage basin (relatively high mean annual precipitation) along with the catchment geology (presence of highly erodible formations) are characteristics favorable for weathering and erosion in the area of the catchment. Large amounts of sediments supplied by erosion are transported down the valley of the river to the coast. In addition, the characteristics of the South Evoikos Gulf (relatively low tidal range, not strong enough waves, and longshore currents to remove all, or at least most, of the sediments deposited by the river and gentle slope of the sea floor around the river mouth) have permitted long-term sediment accumulation and the formation of the fan delta.

The study of the core logs showed that, for a short period of time during the late Holocene, North and South Evoikos Gulfs were joined and most of the fan delta plain was a shallow marine environment while the area of the modern city of Chalkis and Vathrovouni hill was an island.

At the palaeo-lobe of Nea Lampsakos, two sedimentary units have been recognized. The lower one is indicative of a relatively high energy, shallow marine to slightly brackish depositional environment with intervals of riverine influence from at least $7090 \pm 270$ years BP to $6580 \pm 310$ years $\mathrm{BP}$ when a change of the depositional environment occurred to a more sheltered brackish lagoonal one. Mean long-term sediment accumulation rate at this part of the fan delta was approximately $4.5 \mathrm{~mm} /$ year for the first time period (between $7090 \pm 270$ years BP and $6580 \pm 310$ years BP) while sedimentation rates for the period after $6580 \pm 310$ years BP was much lower $(0.2 \mathrm{~mm} /$ year between $6580 \pm 310$ and $4530 \pm 220$ years BP, which increases to $0.51 \mathrm{~mm} /$ year for the last $4530 \pm 220$ years $\mathrm{BP})$ due to the establishment of a sheltered lagoonal environment. The 2050 year time lag (6580 $\pm 310-4530 \pm 220$ years) is indicative of a rapid truncation event and may not correspond to a period of decreased sedimentation rate. 
The main distributary channel changed its course several times leading to the building and subsequent abandonment of at least five fan delta lobes (at today's Liani Ammos, Nea Lampsakos, Agios Nikolaos, Bourtzi, and Kambos), through which the fan delta has advanced during the late Holocene. The most recently abandoned river course is a channel west of the present active one which leads to Bourtzi, northwest of the present active mouth of the river. This channel is depicted in a bathymetric chart of the western part of the Evripos channel surveyed in 1846-1947 by Thomas Graves [62]. The abandoned channels of Bourtzi and Agios Nikolaos have been activated during a severe rainfall event in 2009.

Most of the coastline is generally stable due to relatively long-term quiet marine conditions, whereas progradation occurs only in the area around the recent river mouth. It is estimated that during the last 163 years the area of the active river mouth has advanced about $500 \mathrm{~m}$ while a mean annual progradation rate of about $+3.2 \mathrm{~m} /$ year is observed for the time period between 1945 and 2009 . Approximately $2.0 \mathrm{~km}$ of the coastline of the eastern Kampos abandoned fan delta lobe is undergoing active marine erosion with a maximum mean retreat rate of $-0.94 \mathrm{~m} /$ year over the 64 -year period between 1945 and 2009. The most recent change along the fan delta shoreline occurred during the 2009 extreme flash flood event where nearly $0.7 \mathrm{~km}$ of the coastline along the Bourtzi marshy wetland, northwest of the river mouth, has suffered severe erosion and the shape of the coastline changed significantly from straight to jagged while part of the coastal road was destroyed.

Our future plans include a number of extra shallow drills in the fan delta plain in order to draw more precise conclusions about the evolution of the Lilas River fan delta plain during the late Holocene.

Author Contributions: Geomorphological mapping, E.K., K.V., I.T, K.T., V.B., G.T., and C.G.; Core drilling, E.K., K.V., K.T., V.B., and G.T.; OSL dating of sediment samples, I.T., C.G., K.S., and K.I.; Micropalaeontological analysis of sediment samples, G.I.; Grain size analysis E.K., K.V., and G.T.; Shoreline changes, C.G.; Supervision, E.K.; Writing-original draft, E.K., I.T., and G.I.

Funding: This research received no external funding.

Acknowledgments: We would like to thank the Editors of the Journal, as well as the anonymous reviewers for their comments and corrections that significantly improved the paper.

Conflicts of Interest: The authors declare no conflict of interest.

\section{References}

1. Gaki-Papanastassiou, K.; Cundy, A.B.; Maroukian, H. Fluvial versus tectonic controls on the late Holocene geomorphic and sedimentary evolution of a small Mediterranean fan delta system. J. Geol. 2011, 119, 221-234. [CrossRef]

2. Haslett, S. Coastal Systems, 3rd ed.; University of Whales Press: Cardiff, UK, 2016.

3. Syvitski, J.P.; Saito, Y. Morphodynamics of deltas under the influence of humans. Glob. Planet. Chang. 2007, 57, 261-282. [CrossRef]

4. Coleman, J.M.; Wright, L.D. Modern river deltas: Variability of processes and sand bodies. In Deltas, Models for Exploration; Brousard, M.L., Ed.; Houston Geological Society: Houston, TX, USA, 1975; pp. $99-149$.

5. Galloway, W.E. Process framework for describing the morphologic and stratigraphic evolution of deltaic depositional systems. In Deltas, Models for Exploration; Brousard, M.L., Ed.; Houston Geological Society: Houston, TX, USA, 1975; pp. 87-98.

6. Bergillos, R.J.; López-Ruiz, A.; Ortega-Sánchez, M.; Masselink, G.; Losada, M.A. Implications of delta retreat on wave propagation and longshore sediment transport-Guadalfeo case study (southern Spain). Mar. Geol. 2016, 382, 1-16. [CrossRef]

7. Bergillos, R.J.; Ortega-Sánchez, M. Assessing and mitigating the landscape effects of river damming on the Guadalfeo River delta, southern Spain. Landsc. Urban Plan. 2017, 165, 117-129. [CrossRef]

8. Yang, S.L.; Milliman, J.D.; Li, P.; Xu, K. 50,000 dams later: Erosion of the Yangtze River and its delta. Glob. Planet. Chang. 2011, 75, 14-20. [CrossRef]

9. Fan, H.; Huang, H.; Zeng, T. Impacts of anthropogenic activity on the recent evolution of the Huanghe (Yellow) River Delta. J. Coast. Res. 2006, 22, 919-929. [CrossRef] 
10. Le, T.V.H.; Nguyen, H.N.; Wolanski, E.; Tran, T.C.; Haruyama, S. The combined impact on the flooding in Vietnam's Mekong River delta of local man-made structures, sea level rise, and dams upstream in the river catchment. Estuar. Coast. Shelf Sci. 2007, 71, 110-116. [CrossRef]

11. Abam, T.K.S. Impact of dams on the hydrology of the Niger Delta. Bull. Eng. Geol. Environ. 1999, 57, $239-251$. [CrossRef]

12. Anthony, E.J.; Almar, R.; Aagaard, T. Recent shoreline changes in the Volta River delta, West Africa: The roles of natural processes and human impacts. Afr. J. Aquat. Sci. 2016, 41, 81-87. [CrossRef]

13. Frihy, O.E.; Komar, P.D. Long-term shoreline changes and the concentration of heavy minerals in beach sands of the Nile Delta, Egypt. Mar. Geol. 1993, 115, 253-261. [CrossRef]

14. Frihy, O.E.; Debes, E.A.; El Sayed, W.R. Processes reshaping the Nile delta promontories of Egypt: Pre-and post-protection. Geomorphology 2003, 53, 263-279. [CrossRef]

15. Sabatier, F.; Maillet, G.; Provansal, M.; Fleury, T.J.; Suanez, S.; Vella, C. Sediment budget of the rhône delta shoreface since the middle of the 19th century. Mar. Geol. 2006, 234, 143-157. [CrossRef]

16. Sabatier, F.; Samat, O.; Ullmann, A.; Suanez, S. Connecting large-scale coastal behaviour with coastal management of the Rhône delta. Geomorphology 2009, 107, 79-89. [CrossRef]

17. Jiménez, J.; Sánchez-Arcilla, A.; Valdemoro, H.I.; Gracia, V.; Nieto, F. Processes reshaping the Ebro delta. Mar. Geol. 1997, 144, 59-79. [CrossRef]

18. Jiménez, J.A.; Sánchez-Arcilla, A. Medium-term coastal response at the Ebro delta, Spain. Mar. Geol. 1993, 114, 105-118. [CrossRef]

19. Simeoni, U.; Corbau, C. A review of the Delta Po evolution (Italy) related to climatic changes and human impacts. Geomorphology 2009, 107, 64-71. [CrossRef]

20. Simeoni, U.; Fontolan, G.; Tessari, U.; Corbau, C. Domains of spit evolution in the Goro area, Po Delta, Italy. Geomorphology 2007, 86, 332-348. [CrossRef]

21. Vespremeanu-Stroe, A.; Constantinescu, S.; Tatui, F.; Giosan, L. Multi-decadal evolution and North Atlantic Oscillation influences on the dynamics of the Danube Delta shoreline. J. Coast. Res. 2007, 50, 157-162.

22. Tatui, F.; Vespremeanu-Stroe, A.; Preoteasa, L. Alongshore variations in beach-dune system response to major storm events on the Danube Delta coast. J. Coast. Res. 2014, 70, 693-699. [CrossRef]

23. Pranzini, E. Updrift river mouth migration on cuspate deltas: Two examples from the coast of Tuscany (Italy). Geomorphology 2001, 38, 125-132. [CrossRef]

24. Jabaloy-Sánchez, A.; Lobo, F.J.; Azor, A.; Bárcenas, P.; Fernández-Salas, L.M.; del Río, V.D.; Pérez-Peña, J.V. Human-driven coastline changes in the Adra River deltaic system, southeast Spain. Geomorphology 2010, 119, 9-22. [CrossRef]

25. Gaki-Papanastassiou, K.; Maroukian, H.; Pavlopoulos, K.; Zamani, A. The implications of the expected sea-level rise on the low-lying areas of continental Greece in the next century. In Proceedings of the International Symposium on Engineering Geology and the Environment, Athens, Greece, 23-27 June 1997; pp. 121-126.

26. Karymbalis, E.; Gaki-Papanastassiou, K. Geomorphological study of the river deltas of Pinios, Kalamas, Evinos and Mornos. In Proceedings of the 4th Pan-Hellenic Conference on Coastal Zones Management, Mytilini, Greece, 23-27 September 2008; pp. 86-94.

27. Piper, D.J.W.; Panagos, A.G. Growth patterns of the Acheloos and Evinos deltas, Greece. Sediment. Geol. 1981, 28, 111-132. [CrossRef]

28. Stournaras, G. Assessment of morphometric parameters of Greek Rhone-type deltas. Hydrogeologic and environmental aspects. Environ. Geol. 1999, 38, 53-58. [CrossRef]

29. Maroukian, H.; Karymbalis, E. Geomorphic evolution of the fan delta of the Evinos river in western Greece and human impacts in the last 150 years. Z. Geomorphol. 2004, 48, 201-217.

30. Karymbalis, E.; Chalkias, C.; Stournaras, G. Quantitative Morphometric Analysis of the Evinos River Delta (Western Greece). In Proceedings of the Eighth International Conference on the Mediterranean Coastal Environment-MEDCOAST 07, Alexandria, Egypt, 13-17 November 2007; Volume 2, pp. 1333-1344.

31. Vott, A.; Schriever, A.; Handl, M.; Brückner, H. Holocene palaeogeographies of the central Acheloos River delta (NW Greece) in the vicinity of the ancient seaport Oiniadai. Geodin. Acta 2007, 20, 241-256. [CrossRef]

32. Ghilardi, M.; Fouache, E.; Queyrel, F.; Syrides, G.; Vouvalidis, K.; Kunesch, S.; Styllas, M.; Stiros, S. Human occupation and geomorphological evolution of the Thessaloniki Plain (Greece) since mid Holocene. J. Archaeol. Sci. 2008, 35, 111-125. [CrossRef] 
33. Parcharidis, I.; Kourkouli, P.; Karymbalis, E.; Foumelis, M.; Karathanassi, V. Time series synthetic aperture radar interferometry for ground deformation monitoring over a small scale tectonically active deltaic environment (Mornos, Central Greece). J. Coast. Res. 2013, 29, 325-338. [CrossRef]

34. Karymbalis, E.; Gaki-Papanastassiou, K.; Tsanakas, K.; Ferentinou, M. Geomorphology of the Pinios River delta, Greece. J. Maps 2016, 12, 12-21. [CrossRef]

35. Lambeck, K. Sea-level change and shoreline evolution in Aegean Greece since Upper Palaeolithic time. Antiquity 1996, 70, 588-611. [CrossRef]

36. Lambeck, K.; Purcell, A. Sea-level change in the Mediterranean Sea since the LGM: Model predictions for tectonically stable areas. Quat. Sci. Rev. 2005, 24, 1969-1988. [CrossRef]

37. Bruckner, H.; Vott, A.; Schriever, A.; Handl, M. Holocene delta progradation in the eastern Mediterranean —Case studies in their historical context. Mediterranee 2005, 104, 95-106. [CrossRef]

38. Institute of Geology and Mineral Exploration. General Geological Map of Greece, Sheet of Evia Island (Scale 1:200,000); Institute of Geology and Mineral Exploration: Athens, Greece, 1967.

39. Katsafados, P.; Kalogirou, S.; Papadopoulos, A.; Korres, G. Mapping long-term atmospheric variables over Greece. J. Maps 2012, 8, 181-184. [CrossRef]

40. Anastasakis, G.; Piper, D.J.; Dermitzakis, M.D.; Karakitsios, V. Upper Cenozoic stratigraphy and palaeogeographic evolution of Myreoonnd adjacent basins, Aegean Sea, Greece. Mar. Pet. Geol. 2006, 23, 353-369. [CrossRef]

41. Ambrasseys, N.N.; Jackson, J.A. Seismicity and associated strain of central Greece between 1890 and 1988. Geophys. J. Int. 1990, 101, 663-708. [CrossRef]

42. Roberts, S.; Jackson, J. Active normal faulting in Central Greece: An overview. Geol. Soc. Lond. Spec. Publ. 1991, 56, 125-142. [CrossRef]

43. Goldsworthy, M.; Jackson, J. Migration of activity within normal faults system: Examples from the Quaternary of mainland Greece. J. Struct. Geol. 2001, 23, 489-506. [CrossRef]

44. Drakopoulos, I.; Makropoulos, K.; Stavrakakis, G. Junction of Evia-Beotia and Chalkida Diversion, Seismological Study; Report for Greek Ministly of Public Works: Athens, Greece, 1984.

45. Rondoyanni, T.; Galanakis, D.; Georgiou, C.; Baskoutas, I. Identifying fault activity in the Central Evoikos Gulf (Greece). Bull. Geol. Soc. Greece 2007, 40, 439-450. [CrossRef]

46. Papazachos, V.; Papazachos, B.; Papazachou, C.; Papazachou, K. The earthquakes of Greece; Ziti Publishing: Thessaloniki, Greece, 1997.

47. Roumelioti, Z.; Kiratzi, A.; Benetatos, C. Time-Domain Moment Tensors for shallow ( $\mathrm{h} \leq 40 \mathrm{~km}$ ) earthquakes in the broader Aegean Sea for the years 2006 and 2007: The database of the Aristotle University of Thessaloniki. J. Geodyn. 2011, 51, 179-189. [CrossRef]

48. Perissoratis, C.; Van Andel, T.H. Sea-level changes and tectonics in the Quaternary extensional basin of the South Evoikos Gulf, Greece. Terra Nova 1991, 3, 294-302. [CrossRef]

49. Philip, H. Etude Neotectonique des Rivages Egeenes en Locride et en Eubee Nord Occidentale (Grececentrale). Ph. D. Thesis, These 3me Cycle. Universite de Monpellier, Monpellier, France, 1974.

50. Karageorgis, A.; Anagnostou, C.H.; Sioulas, A.; Eleftheriadis, G.; Tsirambides, A. Distribution of surficial sediments in the Southern Evoikos and Petalioi Gulfs, Greece. Mediterr. Mar. Sci. 2000, 1, 111-121. [CrossRef]

51. Soukisian, T.; Hatzinaki, M.; Korres, G.; Papadopoulos, A.; Kallos, G.; Anadranistakis, E. Wave and Wind Atlas of the Hellenic Seas; Hellenic Centre for Marine Research Publication: Anavyssos, Greece, 2007.

52. Tsimplis, M.N.; Blackman, B. Extreme sea-level distribution and return periods in the Aegean and Ionian Seas. Estuar. Coast. Shelf Sci. 1997, 44, 79-89. [CrossRef]

53. Tsimplis, M.N. Tidal oscillations in the Aegean and Ionian Seas. Estuar. Coast. Shelf Sci. 1994, 39, $201-208$. [CrossRef]

54. Tsimplis, M.N. Tides and sea-level variability at the straight of Euripus. Estuar. Coast. Shelf Sci. 1997, 44, 91-101. [CrossRef]

55. Tsodoulos, I.M.; Stamoulis, K.; Caputo, R.; Koukouvelas, I.; Chatzipetros, A.; Pavlides, S.; Gallousi, C.; Papachristodoulou, C.; Ioannides, K. Middle-Late Holocene earthquake history of the Gyrtoni Fault, Central Greece: Insight from optically stimulated luminescence (OSL) dating and paleoseismology. Tectonophysics 2016, 687, 14-27. [CrossRef]

56. Duller, G.A.T. Distinguishing quartz and feldspar in single grain luminescence measurements. Radiat. Meas. 2003, 37, 161-165. [CrossRef] 
57. Duller, G.A.T. Single-grain optical dating of Quaternary sediments: Why aliquot size matters in luminescence dating. Boreas 2008, 37, 589-612. [CrossRef]

58. Bøtter-Jensen, L.; Thomsen, K.J.; Jain, M. Review of optically stimulated luminescence (OSL) instrumental developments for retrospective dosimetry. Radiat. Meas. 2010, 45, 253-257. [CrossRef]

59. Murray, A.S.; Wintle, A.G. Luminescence dating of quartz using an improved single-aliquot regenerative-dose protocol. Radiat. Meas. 2000, 32, 57-73. [CrossRef]

60. Liritzis, I.; Stamoulis, K.; Papachristodoulou, C.; Ioannides, K. A re-evaluation of radiation dose-rate conversion factors. Mediterr. Archaeol. Archaeom 2013, 13, 1-15.

61. Durcan, J.A.; King, G.E.; Duller, G.A.T. DRAC: Dose rate and age calculator for trapped charge dating. Quat. Geochronol. 2015, 28, 54-61. [CrossRef]

62. Graves, T. Map of Talanta (Evoikos) Channel and the Western Part of the Euripo (Evripo) Channel; British Admiralty: London, UK, 1848.

63. Maroukian, H.; Gaki-Papanastassiou, K. Palaeogeographic evolution of the broader area of Lilas River in Central Evia during the Quaternary. In Proceedings of the 6th Pan-Hellenic Geographical Conference, Thessaloniki, Greece, 3-6 October 2002; pp. 176-184.

64. Ghilardi, M.; Fachard, S.; Pavlopoulos, K.; Psomiadis, D.; Collana, C.; Bicket, A.; Crest, Y.; Bonneau, A.; Delanghe-Sabatier, D.; Knodel, A.; et al. Reconstructing mid-to-recent Holocene paleoenvironments in the vicinity of ancient Amarynthos (Euboea, Greece). Geodin. Acta 2012, 25, 38-51. [CrossRef]

65. Ghilardi, M.; Psomiadis, D.; Pavlopoulos, K.; Çelka, S.M.; Fachard, S.; Theurillat, T.; Verdan, S.; Knodel, A.; Theodoropoulou, T.; Bicket, A.; et al. Mid-to Late Holocene shoreline reconstruction and human occupation in Ancient Eretria (South Central Euboea, Greece). Geomorphology 2014, 208, 225-237. [CrossRef]

66. Aitken, M.J. Thermoluminescence Dating; Academic Press: London, UK, 1985.

67. Prescott, J.R.; Hutton, J.T. Cosmic ray contribution to dose rates for luminescence and ESR dating: Large depths and long-term time variations. Radiat. Meas. 1994, 23, 497-500. [CrossRef]

68. Galbraith, R.F.; Roberts, R.G.; Laslett, G.M.; Yoshida, H.; Olley, J.M. Optical dating of single and multiple grains of quartz from Jinmium rock shelter, northern Australia: Part I, experimental design and statistical models. Archaeometry 1999, 41, 339-364. [CrossRef]

69. Perissoratis, C.; Mettos, A.; Van Andel, T. Structure of the South Evoikos Gulf and the greater Neogene basin. Bull. Geol. Soc. Greece 1989, XXIII/1, 209-221, (In Greek with English abstract). 